\title{
Import Substitution Technology and Machinery as the Basis for Eliminating Food Dependence of Russia
}

\author{
N.K. Mazitov \\ corresponding member of RAS, professor of Kazan State \\ Agricultural University, scientific advisor of Yaroslavovich \\ Production Company
}

\section{R.S. Rakhimov}

Doctor of Sciences (Engineering), professor of South Ural State Agrarian University

\section{N.T. Sorokin}

Doctor of Sciences (Economics), deputy director of AllRussian Institute of agricultural engineering

\author{
L.Z. Sharafiev \\ Candidate of Sciences (Engineering), doctoral student of \\ Kazan State Agricultural University
}

\section{I.R. Rakhimov}

Candidate of Sciences (Engineering), head of Department of agricultural machinery of LLC Chelyabinsk Compressor Plant

\section{D.A. Yalaletdinov}

director of LLC Research Institute of Tractor Machinery, Chelyabinsk
Annotation-The crop capacity in different soil and climatic zones depends on implemented technologies of tillage and sowing, crop rotation and type of work tools of the machinery complex. In every zone, main and additional tilling should be made with different work tool types and to different depth corresponding to the zone conditions. The tillage should also provide conditions for plant growth and development, as well as accumulation and rational usage of accumulated moisture during the whole vegetation period. The work demonstrates that tillage by foreign machinery not tailored to Russian conditions as compared to locally produced machines withers the soil away, reduces crop capacity and increases the base costs. In this connection, the team of researchers has elaborated a universal technology for soil treatment and types of work tools for machines to put it into life. Having said that, the type and dimensions of farms dictates the degree of universalization of newly created machines, so they should have replaceable working elements or interchangeable modules. The methods for determining the metal consumption for machines of different type, their draught resistance and performance of equipment were developed; the calculations are also presented. The study yields dependencies that allow establishing adequate velocities of equipment and operating width of tilling and sowing machines that ensure maximum performance of equipment with tractors having different draught class. The parameters of machines are used by the engineers of LLC Chelyabinsk Compressor Plant, LLC Varnaagromash and Yaroslavovich Production Company for designing and putting into production a complex of tillage and sowing machinery for tractors of draught class 1,$4 ; 3 ; 5$ and $6-7$. The developed complex of machines performs all components of tillage technologies for specific working conditions and corresponds to functional specifications of agricultural machinery, environment protection, ergonomics and energy saving. Thus, the developed import-substitution technology and complex of machines enable increased crop capacity and reduced base cost of cultivated crops, which is the basis for liquidation of food dependence of Russia.

Keywords-Import substitution, technology, complex of machines, metal consumption, draught resistance, performance, moisture accumulation, moisture retention, crop capacity, base costs.

\section{INTRODUCTION}

Soil and climate conditions of different zones in Russia are greatly diverse. They differ by temperature and precipitation during a year and vegetation period, field relief, soil type and properties, its susceptibility to different types of erosion and other factors. The study results obtained for different zones show that without regard to the afore mentioned factors of the crop rotation system accepted in the zone, the biggest crop capacity is ensured by the technology that includes primary cultivation in autumn, mulching, presowing cultivation and sowing in spring [1-3]. For every zone, according to weather and climate conditions, the methods of primary and presowing cultivation and sowing should correspond to different types of work tools and depth providing conditions for development and growth of soil and crops; also, accumulation and rational use of moisture should persist during the whole vegetation period [4-6, 18]. 
Similar data were obtained by foreign researchers [10-16]. These works establish the work tool parameters to provide better soil pulverization at minimal draught resistance of the work tools [11]; they also study energy consumption by different crop production technologies and method for tractor draught class selection according to the tillage technology [12], develop an approach to justification of the design of tillage machines to provide their reliability [13], study the effect of work tool type, tillage depth and velocity on productivity of tillage machines on clay soils and necessitate their alignment [14], investigate the impact of tillage depth and velocity on draught resistance when working with different types of work tools $[15,16]$.

Existing tillage technologies (conventional, soil protective, minimal and zero), envisaging yearly implementation of the same tillage and sowing machines become ineffective and do not increase crop capacity. This is why in Russia and abroad researchers look into different technologies, including improvement of existing ones, and develop new tillage and sowing machines with different types of work tools. This work presents the suggested technology and machinery complex for its realization in tillage of crops under various soil and climate conditions of Russia ensuring minimal draught resistance and maximal productiveness with compliance with agrotechnical requirements to tillage.

\section{RESEARCH GOAL.}

Development of versatile energy saving tillage technology with its implementation into Russian import substituting machinery complex having high competitiveness on the world market with application in different soil and climate zones to get guaranteed and ecologically safe crops.

\section{METHODS.}

Implementation of a reduced version of existing tillage technologies using foreign heavy tractors with tillage and sowing units featuring pneumatic seeding had the following negative consequences in many farms [6-7]:

- exclusion from the technology of autumn moisture retention techniques (moldboarding, paraploughing, moling, flat-blade cultivation);

- failure to meet requirements to crop rotation and humus accumulation;

- overcompaction of fields by heavy machines, which prevents moisture penetration into deeper layers;

- failure to meet agrotechnical requirements to ridgeness and soil pulverization leading to moisture evaporation;
- nonuniform embedding of seeds into soil, which leads to nonuniform and depauperate sprouts, their nonuniform ripening and guaranteed decrease in crop capacity;

- high base cost of grain due to low gather, high expenses for depreciation of foreign machinery;

- forced high expenses for herbicides at minimal soil tillage.

This results in downfall of farmers, critical insufficiency of local products of plant and cattle breeding and decay of villages which are the sources of healthy life.

These downturns can be eliminated by the uptake of locally produced machines. As an example, Fig. 1 presents the results of tests with similar tillage technologies using locally produced and foreign machines for certain operations, which demonstrate the advantage of new local machinery.

The experimental fields of Tatar Agricultural Research Institute were used to test tillers $\mathrm{KBM}-4,2 \mathrm{~N}$ for presowing cultivation; in acutely drought 2010, average grain crop capacity was $16.3 \mathrm{q} / \mathrm{ha}$, while across Republic of Tatarstan the crop capacity without these tillers was only $9.8 \mathrm{q} / \mathrm{ha}$, i.e. the shortage was $6.5 \mathrm{q} / \mathrm{ha}$. This is the due to disregard of moisture accumulation and preservation techniques.

A particular attention should be paid to the experience of implementation of modular machinery of Yaroslavovich Production Company for presowing cultivation in Krasnodar Krai.

There are colossal advantages of $\mathrm{KBM}-7,2 \mathrm{P}$ tillers versus KPS-4 on the fields of Ust-Labinsk district of Krasnodar Krai:

- The operating width is 1.8 times more $(7.2$ vs. $4.0 \mathrm{~m})$;

- Operating velocity is 1.5 time higher (15 vs. $10 \mathrm{~km} / \mathrm{h})$;

- The number of passes is 4 times fewer.

- The fuel economy is 2.3 times for a single pass $(1.8$ and $4.1 \mathrm{~kg} / \mathrm{ha}$ ).

Tables 1 and 2 hold the results of comparative field experiments studying the impact of presowing cultivation methods on crop capacity, soil moisture, grain base cost, production profitability depending on usage of locally produced and foreign machinery. 

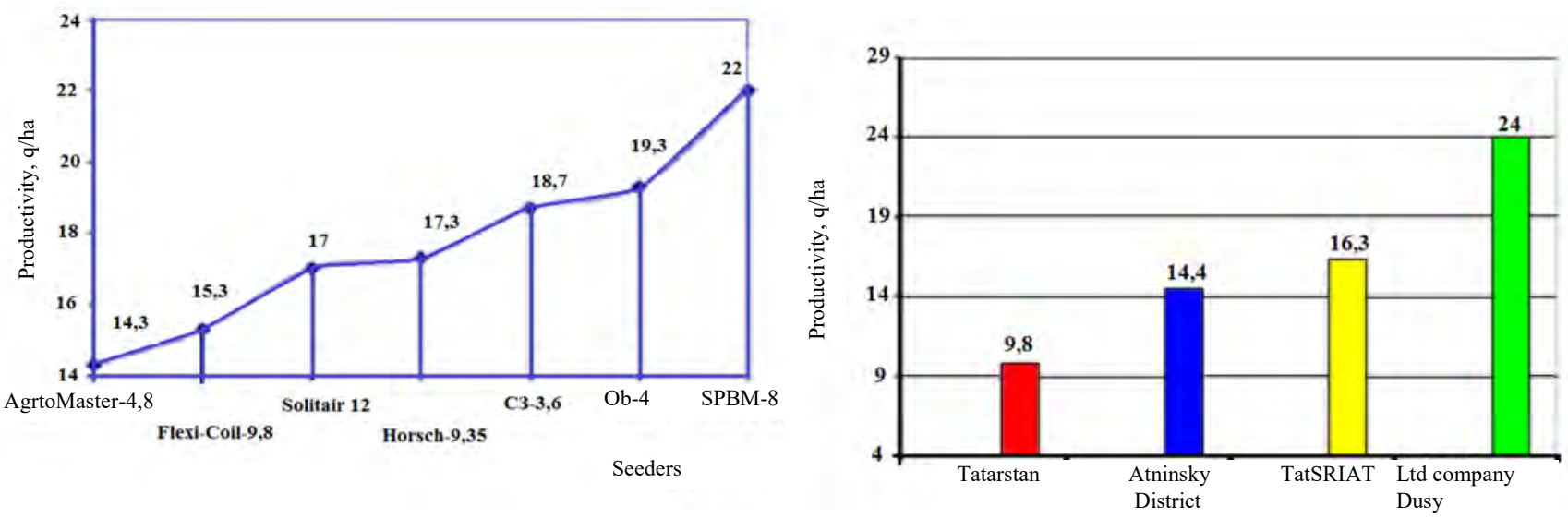

Fig. 1. a - Crop capacity of summer wheat in draught $2008(50.9 \mathrm{~mm})$ in Kuzaikino village (Almetyevsk district of Republic of Tatarstan) after using different sowers: Our SPBM-8 sower, produced by LLC Varnaagromash in Chelyabinsk region, increased gather by $50-80 \%$ as compared to foreign systems. $b-$ Barley crop capacity in Republic of Tatarstan in acutely drought 2010. $24 \mathrm{q} / \mathrm{ha}$ instead of $9.8 \mathrm{q} / \mathrm{ha}$ gathered after presowing cultivation by KBM-4,2 tiller made in Yaroslavl. Production demonstration of advantage of local import-substituting machinery over foreign systems and out-dated local machines.

TABLE I. ALTERATION OF MOISTURE ON 10TH DAY AFTER SUMMER WHEAT SOWING IN 2010.

\begin{tabular}{|c|c|c|c|c|c|c|c|}
\hline \multirow{2}{*}{ Parameters } & \multicolumn{7}{|c|}{ Sampling depth $[\mathrm{cm}]$} \\
\hline & 0-10 & $10-20$ & $20-40$ & $40-60$ & $60-80$ & 80-100 & Total \\
\hline $\begin{array}{l}\text { Initial soil moisture before presowing } \\
\text { cultivation [\%] as of May } 2,2010\end{array}$ & 17.0 & 21.3 & 35.3 & 30.3 & 33.9 & 29.4 & 167.2 \\
\hline $\begin{array}{l}\text { Soil moisture after presowing cultivation } \\
\text { by KBM-4,2 tiller } \\
\text { on the } 10 \text { th day after sowing [\%] } \\
\text { May } 12,2010\end{array}$ & 12.9 & 14.9 & 32.0 & 27.2 & 16.9 & 3.6 & 107.5 \\
\hline $\begin{array}{l}\text { Soil moisture after presowing cultivation } \\
\text { by KPS- } 4+4 \text { BZSS- } 1 \text { tiller } \\
\text { on the } 10 \text { th day after sowing [\%] } \\
5 / 12 / 2010\end{array}$ & 7.7 & 12.6 & 18.8 & 4.3 & 10.7 & 1.2 & 55.3 \\
\hline
\end{tabular}

Multiyear testing of 33 machines on the area of more than 250K hectares (over 2006-2017) by JSC Vostok Zernoproduct (Republic of Tatarstan, Ulyanovsk and Voronezh regions) in each of the years demonstrated crop capacity from 30 to 25 $\mathrm{q} / \mathrm{ha}$ of ecologically safe grain, which is impossible using foreign machinery. Taking into account positive features of existing technologies, a team of researchers from RAS, AllRussian Institute of Agricultural Engineering, educational and scientific institutions has developed a versatile resourcesaving tiling and sowing technology that includes autumn after-harvest surface moisture accumulating stubble tilling to the depth of 3-5 $\mathrm{cm}$, primary underwinter moldboard or nonmoldboard tilling to the depth of 10-30 $\mathrm{cm}$ and deep moisture accumulating chisel tilling (once per crop rotation) to the depth of 35-45 cm and spring mulching tilling to the depth of seed embedding, then mulching smoothing presowing cultivation to the same depth with creation of consolidated seedbed with harrowing out pests in their early growing stage, and sowing with fertilization by row, narrow-row, wide-row or widespread methods [5].

During crop rotation over the subsequent years along with moisture accumulation and depending on the drought level and soil conditions, one can perform only primary moisture absorbing tilling to necessary depth, depending on grown crops, by a suitable work tool, spring moisture preserving presowing cultivation and crop sowing. When sowing grain crops, the presowing tilling and sowing can be combined using tilling-sowing machines.

The peculiarity of suggested technology is in applicability under extreme conditions: in the case of excess moisture accumulate it below ploughing layer preventing formation of wet depressions and limans, as well as floods wetting the fertile layer; and in the case of drought, preserve accumulated moisture until crops ripen after sustaining drying evaporation. 
TABLE II. EFFICACY OF THREE PRESOWING TILLING METHODS BEFORE ESTER SUMMER WHEAT SOWING IN YULBAT AGRICULTURE ENTERPRISE, LLC, IN SABINSK DISTRICT OF REPUBLIC OF TATARSTAN IN 2012

\begin{tabular}{|l|l|l|l|c|l|l|c|c|c|}
\hline $\begin{array}{l}\text { N } \\
\text { o. }\end{array}$ & $\begin{array}{l}\text { Tilling } \\
\text { method }\end{array}$ & $\begin{array}{l}\text { Hay } \\
\text { heap } \\
\text { mass } \\
{[\mathrm{q} / \mathrm{ha}]}\end{array}$ & $\begin{array}{l}\text { Mass of } \\
\text { roots } \\
{[\mathrm{q} / \mathrm{ha}]}\end{array}$ & $\begin{array}{l}\text { Crop } \\
\text { capacity } \\
{[\mathrm{q} / \mathrm{ha}]}\end{array}$ & $\begin{array}{l}\text { Expenses } \\
\text { for } \\
\text { presowing } \\
\text { tilling } \\
{[\text { RUB/ha }]}\end{array}$ & $\begin{array}{l}\text { Total expenses, } \\
\text { including fall } \\
\text { tillage and } \\
\text { autumn } \\
\text { mulching }\end{array}$ & $\begin{array}{l}\text { Grain base } \\
\text { cost } \\
{[\mathrm{RUB} / \mathrm{a}]}\end{array}$ & $\begin{array}{l}\text { Sales } \\
{[\mathrm{RUB} / \mathrm{q}]}\end{array}$ & $\begin{array}{l}\text { Profit } \\
\text { ability } \\
{[\%]}\end{array}$ \\
\hline 1 & KPS-4 & 22.3 & 17.8 & 16.6 & 298.1 & 696.7 & 620.1 & 550 & -11.3 \\
\hline $\mathbf{2}$ & KBM-4,2 & $\mathbf{2 4 . 2}$ & $\mathbf{2 4 . 5}$ & $\mathbf{2 3 . 6}$ & $\mathbf{5 6 0 . 9}$ & $\mathbf{9 5 9 . 5}$ & $\mathbf{4 4 7 . 3}$ & $\mathbf{5 5 0}$ & $+\mathbf{2 3 . 0}$ \\
3 & Sunflower-5 & 19.1 & 21.0 & 21.6 & 577.0 & 975.6 & 489.5 & 550 & +12.0 \\
\hline
\end{tabular}

The recommended technology for tiling and sowing of crops envisages the application of the following types of working elements [4]:

- for primary tiling: plough-body, duckfoot, chisel work tool or versatile work tool instead of the plough-body, foot and chisel work tool;

- for additional tiling: spring rippers, rippers or feet on a spring S-stand, duckfoot on rigid or sprung stand, disk work tools, rippers;

- for sowing: hoe colters for row sowing with single- or double-row sowing and variable-depth

- embedding of seeds and fertilizers, tine colters for subsoil-widespread sowing and fertilizing;

- for soil rolling: rod rollers with the diameter of $0.25 \mathrm{~m}$ to flatten and mulching the topsoil, create seedbed; rollers with diameter $0.4-0.5 \mathrm{~m}$ with smooth bands or round rods to pulverize large lumps, smoothing and rolling the topsoil, double rollers combining various types of rollers for better tilling of strong soil.

To reduce the number of machines necessary for all technological operations of the recommended cropping technology, new machines should be versatile with interchangeable working elements or modules; to reduce the number of passes along the field, they should be combined to perform several operations in one pass.

The degree of machinery universalization depends on the ploughland area and farm area of activity, number and draught class of tractors available. The calculations have demonstrated that farms with the ploughland area of 1000-1200 ha, crop rotation with sowing of various crops requires one tool for a tractor of draught class 3 with complete universalization, able to perform all types of primary and additional tilling and crop sowing using interchangeable working elements and modules. For average-sized farms with ploughland area of $7-10 \mathrm{~K}$ ha, versatile tools are required for tractors of 3-5th draught class with interchangeable working elements for tilling (moldboard, non-moldboard, chisel), with interchangeable modules for tiling to the depth of $0.1-0.16 \mathrm{~m}$ and tilling and sowing machines with interchangeable modules for mulching, presowing tilling and sowing with different types of working elements to the depth of $0.06-0.1 \mathrm{~m}$. Large agricultural holdings need single-operation combines for all technological operations performed by tractors of draught class 5-8 [4].

With regard to everything above, the new tilling and sowing machinery complex should [4]:

- correspond to the requirements of cropping in crop rotation and soil-climate conditions of the zone;

- meet the requirements to agricultural machinery in relation to tilling depth, pulverization, stubble preservation, etc.

- have:

- low metal consumption;

- high reliability and structural strength;

- low draught resistance;

- large productivity;

- low cost;

- low fuel consumption;

- easy controls and adjustments;

- compliance to safety and ecological requirements.

On the tilling and sowing machines, depending on the working element type and its impact on soil, the working elements on the tool frame should be mounted in staggered order, as symmetrical wedge or using plow configuration with arrangement of working elements in one or more rows. On tilling sowing machines with pneumatic sowing of seeds, the bunker for seeds and fertilizers can be located on a separate trailer in front of or behind the tilling-sowing equipment, on the drawbar hitch or directly on the machine frame. The design affects metal consumption of the machine, its draught resistance and, as a result, the productivity. Work [7] presents the analytical dependencies to determine metal consumption and draught resistance of tilling and sowing machines, as well as the productivity of cultivators depending on the tractor motor power, structural scheme of the machine and its operating conditions in different soil and climatic zones [8-9].

\section{RESULTS AND DISCUSSION}

The elaborated technique was used to determine the metal consumption coefficients, draught resistance and productivity of different types of tillers. Figure 2 exemplifies the g-force of different tool types showing low metal consumption of tools with staggered arrangement of working elements. 
The draught resistance of all machine types, other conditions being equal, depends on their g-force and changes proportionally.

With known values of g-force and draught resistance, we have determined the productivity of cultivators working in combination with tilling and sowing machines with tractors of various draught class. Figure 3 depicts the dependencies of cultivator productivity on the operating width at different cultivator velocities working with the tractor having power of $220 \mathrm{~kW}$ in hard and light conditions.
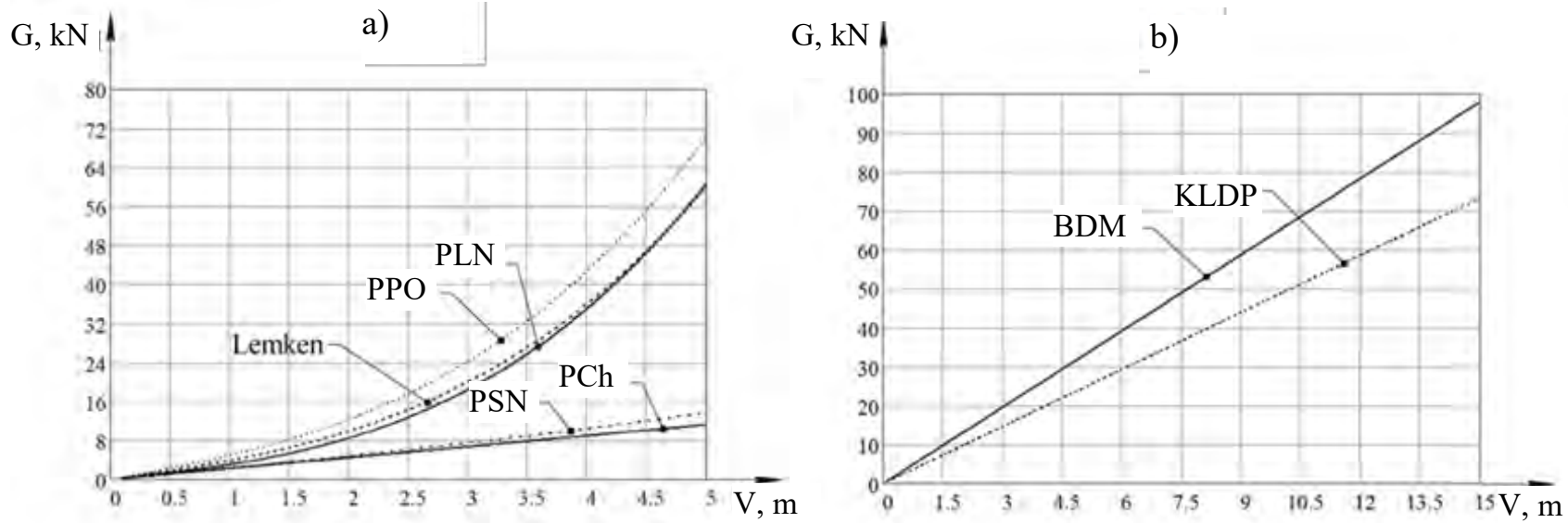

Fig. 2. Dependence of $g$-force $\mathrm{G}(\mathrm{kN})$ on operating width $\mathrm{B}(\mathrm{m})$ : a) for primary tilling; $b$ ) for additional tilling.

a)
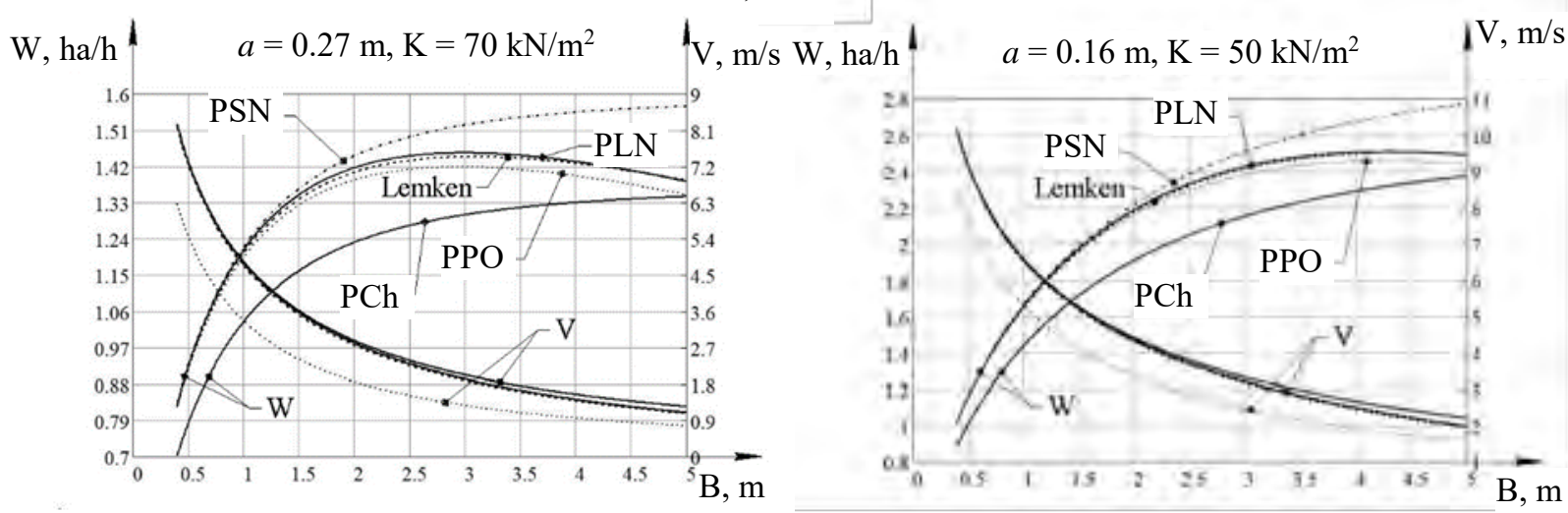

b)
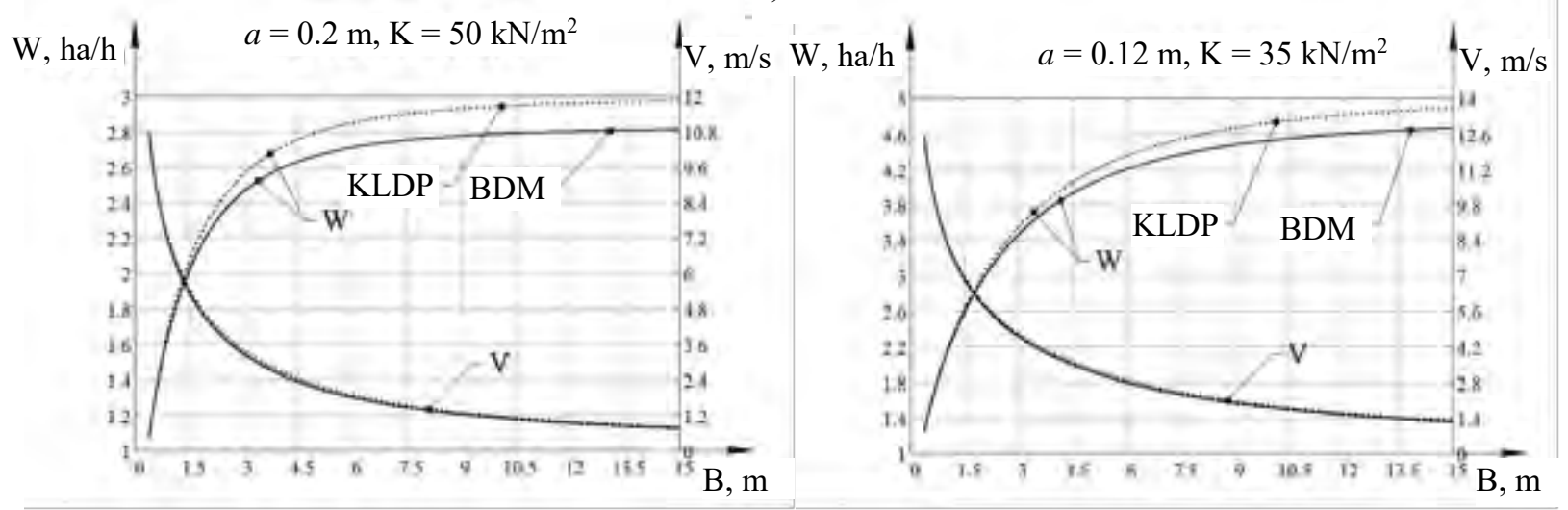

Fig. 3. Dependence of machine productivity $\mathrm{W}(\mathrm{ha} / \mathrm{h})$ on operating width $\mathrm{B}(\mathrm{m})$ for different cultivator velocity $\mathrm{V}(\mathrm{m} / \mathrm{s})$ : $\mathrm{a})$ for primary tilling; $\mathrm{b})$ for additional tilling.

The study yielded dependencies that allow establishing suitable velocities of equipment and operating width of the machine that ensure maximum performance of the cultivator.
The calculations were used to determine rational values of operating width of tilling and sowing machines and cultivator velocity for tractors of draught class 1,$4 ; 3 ; 5$ and 6-7. 
The parameters of machines were used by the engineers of LLC Chelyabinsk Compressor Plant, LLC Varnaagromash and Yaroslavovich Production Company for designing and putting into production a complex of soil-cultivating and sowing machinery for tractors of draught class 1,$4 ; 3 ; 5$ and 6-7 [17].

Thus, the developed complex of tilling and sowing machines with interchangeable working elements and modules with various types of working elements allows for all types of tilling and sowing for the recommended technology

of cropping in different soil and climate conditions of Russia.

The full-scale implementation of recommended technology and machinery complex in the farm of K.I. Shumskikh in drought steppe zone of Chelyabinsk region with the area of $7 \mathrm{~K}$ ha provided the gather, averaged over the recent five years (2013-2017), of 3.0-3.5 t/ha with average crop capacity in the district of $1.4-1.5 \mathrm{t} / \mathrm{ha}$, i.e. the crop capacity of grain crops increases 2 times and more. In such conditions, the base cost of durum wheat was $2527 \mathrm{RUB} / \mathrm{t}$, barley $1985 \mathrm{RUB} / \mathrm{t}$, sunflower seeds $7398 \mathrm{RUB} / \mathrm{t}$, which testifies the possibility of high profitability for cropping grain and other crops in Ural zone.

The developed machinery complex for cropping performs all technological elements accepted for specific conditions of the zone and meets functional requirements to agricultural machinery, environmental safety, ergonomics and energy conservation.

Moreover, the chosen technology and machinery complex yield the products:

- without additives harmful for human;

- without genetically modified breeds;

- without additional water consumption due to soil water conservancy;

- preventing water wind and mechanical erosion, by applying advanced agricultural machinery without deterioration of soil structure, its pulverization and provision of water penetration into lower layers;

- applying crop rotation and local breeds corresponding to the zone;

- meeting the agrotechnical requirements to soil pulverization, topsoil ridgeness, uniformity of tilling and sowing depth and sowing terms allowing for even sprouts and their growing.

- $\quad$ performing presowing tilling with harrowing out weed roots to prevent application of herbicides and create conditions of organic farming;

- eliminating vibrations and creation of adequate working conditions for operator due to flattened field surface, installing automatic systems for adjusting and controlling tilling depth, sowing amount and cultivator working quality;

- creating versatile and combined machine and cultivators with interchangeable working elements and modules made of high-strength steels, provisioned with safety features and vibrators, as well as performing all components of cultivator technological process (transportation, landing, work, tip outs, turns) and having low metal consumption;

- increasing cultivator productivity 2-4 times with decreased demanded power and fuel consumption for functional operations 2-3 times, decreased metal consumption 3-4 times due to creation of versatile and combined machines;

- $\quad$ reducing base cost of plant products due to decreased cost of machines and application of versatile machinery during the whole period of field works;

- eliminating application of heavy foreign agricultural machinery compacting and drying soil;

- implementing scientific results of researchers from RAS and higher education institutions (HEIs) on creation of promising technologies and agricultural machines.

\section{Conclusions.}

After analyzing the works on development of tilling technologies and creation of tilling and sowing machinery complex for various soil and climatic zones, the following conclusions can be drawn:

- our versatile cropping technology developed by RAS and HEIs provides for soil tilling and sowing according to zone conditions meeting agrotechnical requirements and enables high gather and ecologically safe products;

- developed and industrially implemented complex of tilling and sowing machines produced locally, as compared to foreign rivals, executes all elements of technology in correspondence with agrotechnical requirements to conditions of certain zones and provides increased grain crop capacity, has low metal consumption and cost, and as a result reduces the base cost of products.

Thus, we have created an import substituting technology and locally produced complex of machinery that can liquidate the food dependence of Russia.

This is a result of close collaboration of science, education and industry.

\section{References}

[1] A.P. Kozachenko, State, soil and economical estimation and methods for rehabilitation and usage of farming ground of Chelyabinsk region on the basis of adaptive-landscape farming system: monograph, Chelyabinsk: Chelyabinsk State Agroengineering University, 2004, 380 p.

[2] A.G. Taskaeva, V.V. Blednykh, R.S. Rakhimov, Soil tilling: teaching guide. Chelyabinsk: Chelyabinsk State Agroengineering Academy, 2012, 111 p.

[3] V.V. Blednykh, Structure, calculation and design of tilling tools: teaching guide, Chelyabinsk. Chelyabinsk State Agroengineering Academy, 2010, 214 p.

[4] R.S. Rakhimov, S.G. Mudarisov, I.R. Rakhimov, Development of resource-saving technology and justification of machinery complex parameters for cropping in Ural zone, Bulletin of Bashkir State Agrarian University, 2018, No. 2 (46), pp. 121-134.

[5] Soil tilling method,Invention patent No. 2457651 RU, application No. 2011105850, 22 as of February 16, 2011, Issued on August 10, 2012.

[6] N.K. Mazitov, Theory of reactive work tools of tillers/ The Academy of Sciences of the Republic of Tatarstan, Kazan, 2011, 279 p. 
[7] R.S. Rakhimov, Rakhimov I.R., et al., Determining metal consumption of tools during design AIC of Russia. South Ural State Agrarian University, 2015, Vol. 74, pp. 110-118.

[8] G.N. Sineokov, I.M. Panov, Theory and calculation of tillers, Moscow: Mashinostroenie. 1977, 328 p.

[9] M.Z. Tsimmerman, Work tools of tillers, Moscow: Mashinostroenie. 1976,295 p.

[10] A. Kulen, Kh. Kuipers, Modern farming mechanics. translated from English, Moscow: Agropromizdat, 1986, 349 p.

[11] E. McKyes, J. Maswaure, Effect of design parameters of flat tillage tools on loosening of a clay soil, Soil and Tillage Research, Volume 43, Issues 3-4, 10 November 1997, pp. 195-204.

[12] Z.I.Mileusnić, D.V. Petrović, M.S. Đević, Comparison of tillage systems according to fuel consumption, Energy. Volume 35, Issue 1, January 2010, pp. 221-228.

[13] A. Abo Al-kheer, A. El-Hami, M.G. Kharmanda, A.M. Mouazen, Reliability-based design for soil tillage machines, Journal of Terramechanics. Volume 48, Issue 1, February 2011, pp. 57-64.

[14] Saeed Ranjbarian, Mohammad Askari, Javad Jannatkhah, Performance of tractor and tillage implements in clay soil, Journal of the Saudi
Society of Agricultural Sciences. Vol. 16, Issue 2, April 2017, pp. 154162.

[15] Abo Al-kheer, A.El-Hami, M.G.Kharmanda, A.M.Mouazen, Reliabilitybased design for soil tillage machines, AJournal of Terramechanics. Vol. 48, Issue 1, February 2011, pp. 57-64.

[16] A. Ibrahmi, H. Bentaher, E. Hamza, A. Maalej, A.M. Mouazen, Study the effect of tool geometry and operational conditions on mouldboard plough forces and energy requirement: Part 2. Experimental validation with soil bin test, Computers and Electronics in Agriculture, Vol. 117, September 2015, pp. 268-275.

[17] R.S. Rakhimov, V.N. Konovalov, I.R. Rakhimov, D.A. Yalaletdinov, Development and production of machinery complex for cropping in acutely drought conditions, Technologies and mechanization equipment in AIC. Proceedings of international scientific and practical conference of the Agroengineering Institute, Chelyabinsk 2018, pp. 148-155.

[18] S.G. Mudarisov, Z.S. Rakhimov, M.M. Yamaletdinov, I.M. Farkhutdinov, Evaluation of technological process of tilling based on continuum dynamics equations, Achievements of science and engineering of AIC, 2010, No. 1, pp. 63. 